\title{
Opinion \\ Feeding the World and protecting our birds: are the two compatible?
}

\author{
JIM DIXON
}

\section{Farming and birds}

Growing human demands on land use and economic development are clearly central issues for the management of both the World economy and environment. Arresting economic growth is clearly not a realistic option and so conservationists have to find ways of achieving conservation in the context of development, i.e. through sustainable development. Recognized at the "Earth Summit" in Rio de Janeiro in 1992 as the guiding principle for both economic development and environmental protection, this concept is severely tested on one of the most fundamental issues of all: growing our food.

Technological development, land use reforms and growing yields and production are clearly necessary to feed both the current generation and future generations in the developed and developing World. Predictions for World population growth hover around 9-11 billion people (double the current) by 2025. Growing affluence will lead to changes in the nature of diets (especially increased meat consumption in societies where grains have been dominant) and hence World demand for food (Rayment 1995). It was once fashionable to talk of food mountains in Europe, now the reverse problem of food shortage is back on the agenda. What does this mean for conservation? What can we do about it?

Many practical bird conservation problems stem from changing land use. Familiar problems include:

- conversion of grassland, forest, heathland or wetland to agriculture

- increased intensity of farming practices (increased chemical and fertilizer inputs)

- water management to irrigate drylands and drain wetlands

- overgrazing of rangelands, forests and moorlands

- direct and indirect effects of pesticides.

Consistently, the problems of rural land use change and development of farming technologies for increased yields rank among our highest-priority bird conservation problems. Habitat change and the accumulation of pesticides in food chains have been some of the defining issues of the modern conservation movement. Few doubt this, although there is perhaps little agreement on what we should do to resolve it. Our tried and tested "armoury" consisting of sciencebased species management and protection, nature reserves and protected areas and public awareness of birds are increasingly necessary in the face of large-scale 
economic change. But are they enough? Should we also set out to influence the politicians, farmers, businesses and academics who lead farming policy? It would be easy for bird conservationists to retreat into a shell arguing fatalistically, that rural economic development and conservation are irreconcilable; that "no-one" in international political institutions or big "agribusiness" would listen to us; that we must concentrate on nature reserves, scientific ornithology and public awareness; that we should work at changing attitudes at the community level, rather than at the political level; and that we should leave this to government agencies and "environmental" groups to sort out.

I will try and illustrate that bird conservationists have played important roles in influencing agriculture policy in Europe and that we have begun to make a difference. Our experience in Europe illustrates that, given the will, we may yet strike a positive deal with those who drive land use change elsewhere in the World.

\section{Farming and birds in Europe}

We are fortunate now in Europe that there is a rapid growth of scientifically sound, often applied and published case studies of the relationships between birds and farming. Indeed these are the subject of an important recent book (Pain and Pienkowski 1997). Farming and birds in Europe draws on the studies of birds on farmland in the European Union. It also draws on BirdLife International's Europe-wide analyses of the conservation status of all of Europe's birds (Tucker and Heath 1994) and habitats (Tucker and Evans 1997). These three high-quality publications are a damning indictment of an agriculture system and policy in Europe which has caused widespread declines in species and habitats. No other single threat is as serious to Europe's birds as is change on farmland.

Of 514 bird species found regularly in Europe, over half $(54 \%)$ are defined by BirdLife International as "of conservation concern". Some 116 of these are dependent partly or wholly on farmland. Once-common farmland birds are now included in national Red Data lists, which list threatened or endangered birds. These declines are mirrored in declines of plants, invertebrates and mammals and by the continuing destruction and deterioration of designated and undesignated wildlife sites in Europe. Globally threatened species dependent on farmland include:

- Spanish Imperial Eagle Aquila adalberti: restricted to the Iberian peninsula, mainly in Spain where alteration of the traditional "dehesa" and steppe habitats are key threats. A conservation programme involving regional governments includes promoting environmentally sensitive farming.

- Lesser Kestrel Falco naumanni: the western Palearctic population is considered between 10000 and 17000 pairs and probably declining due to intensification of cereal growing over large areas of steppe. Recent research by BirdLife International aims to develop our understanding of factors affecting breeding success.

- Corncrake Crex crex: declining throughout its breeding range in northern and western Europe and dependent on traditionally managed riverine and agricultural grasslands. Conservation measures in the U.K., Ireland and 
France have taught valuable lessons now being applied in the major breeding range in central and eastern Europe.

- Great Bustard Otis tarda: found in central and eastern Europe and Iberia, where considerable threats exist mainly from damaging changes to extensive steppe, cereal and grassland habitats. Conservation measures in Spain and Hungary have involved promoting specified farming systems within government policies.

At national, regional and local level, bird conservationists have been working with farmers, providing advice, assistance and (occasionally) funding to promote specific management for certain species. These programmes are often necessary for widely dispersed species (as most of the declining species on European farmland are). However, it is almost impossible to imagine conservation organizations ever having the resources to work with all on Europe's farmers for the protection of wildlife. This is where awareness campaigns in the farming media and working with policy makers becomes important. Many BirdLife International partners have developed close links with national Ministries of Agriculture (BirdLife International 1997). For example:

- Spain: BirdLife Spain has been developing proposals for extensive cereal and steppe conservation in Castilla y León, Castilla La Mancha, Madrid, Extremadura and Andalucia

- Hungary: BirdLife Hungary has been working with the Ministries of the Environment and Agriculture developing conservation legislation including promotion of extensive farming

- Ireland: the Corncrake Grant Scheme trialled by Birdwatch Ireland has now been adopted as part of the national Rural Environmental Protection Scheme for farmers

- U.K.: experience of "set-aside" land has been used to develop an arable land management scheme devised jointly by the Royal Society for the Protection of Birds (RSPB), English Nature (statutory conservation agency) and the Game Conservancy Trust. This has now been adopted by the Ministry of Agriculture.

Each of these examples shows that through positive and scientifically sound practical experiments, governments and farmers can be persuaded to do practical conservation work for birds. Indeed farmers (if not governments) are often willing partners. This approach has been the bedrock of a more general approach to influencing agriculture policies within the European Union (EU).

The Common Agricultural Policy (CAP) is a massive, complex and politically charged international policy. It now encompasses 15 countries, has an annual budget of 41 ooo million ECU (over $£ 30000$ million) and directly affects the decisions of over 7 million farmers on nearly half of the land surface of Europe. Initially established as a policy to support "efficient" farms and manage the resulting "flight" from the land, the CAP has won many admirers and many critics. Its admirers point to social stability in rural areas, guaranteed quantities of food for European citizens and an advanced farm structure. Critics often acknowledge these benefits but argue that the policy is now a costly, bureaucratic and environmentally destructive anachronism (BirdLife International 1997). 
Many pressures will cause changes in the CAP, not the least being the demands of international trading partners to remove unfair subsidies on production, the difficulties faced by the EU in extending the policy as the EU enlarges and changes in the priorities for EU public spending away from subsidies to farmers.

Currently, the CAP operates mainly by paying subsidies to farmers for production or by artificially adjusting markets so that farmers receive a higher price for their produce. In practice, the policy has become unwieldy and limited in achieving its own aims through its high cost. From the farmers' point of view, it often seems as though their incomes are falling and at the same time the public criticizes the high cost of their subsidies. BirdLife International wishes to see the production subsidies reduced and for these to be replaced with direct contracts between farmers and governments for countryside management. These contracts are already $4 \%$ of CAP spending (at around 1800 million ECU) and we suggest this should rise to $25 \%$ of CAP spending soon. Many would agree with this target but are conservationists being listened too? Will these changes bring any real benefits to birds or are we simply taking part in a large, bureaucratic confidence trick?

BirdLife International has become one of the leading analysts of CAP and environmental issues. This reputation is based on several factors. First, we have undertaken substantial ecological analysis of the relationship between farming and birds and made these results available in highly regarded published forms. Second, the European network has coordinated action through a European Agriculture Taskforce of agriculture and birds specialists. This group meets regularly in Brussels and has steered BirdLife International's input into pan-European agriculture policy. Third, we have developed a programme of policy analysis: reviewing what, in practice, is happening to environmental policies (e.g. BirdLife International 1996a), the world grain market (Rayment 1995) and prospects for "greener" rural development (Cuff and Rayment 1997). Finally, we have ensured that the key decision makers and officials who make decisions on the CAP are fully aware of our views, data, perspective and aspirations for agriculture. In some countries, this is backed by large-scale public campaigns in support of our work.

Bird conservation has become a small, well-organized and effective force for influencing the CAP. We have much more to do and inevitably the oftenstretched and resource-starved organizations across Europe will always be limited in their effect by lack of expertise and people. However, our experience shows that with moderate resources, real commitment and the will to succeed, the voice of bird conservation can be heard and can make a difference. But this is within Europe where there are large and democratic public institutions, where the public are often sympathetic to conservation and where most bird conservation organizations are reasonably well supported. Is it possible to have the same impact in other parts of the world, where resources are even tighter and the conflicts between land use and birds even greater?

\section{Farming and birds in the rest of the World}

It is first necessary to consider the need to take action for birds on farmland or those threatened by farming before considering strategies for resolving these 
problems. Unlike Europe, we do not yet have comprehensive data analyses nor published information outlining the scale and nature of threats from farming. However, empirical knowledge and good examples from across the World suggest strongly that agriculture must rank alongside forest loss, changes in the marine environment and global climate change as priority issues for conservation.

In a preliminary analysis of data held by BirdLife International, Alison Stattersfield and colleagues (BirdLife International 1996b) have drawn some broad conclusions from data on globally threatened species and key habitats. This is highly preliminary data which is limited by poor knowledge of threats to species and very little information on the causes of these threats. However, some examples of the scale of the problems for globally threatened species can be drawn to illustrate the conservation tasks we face. It is important to recognize both the absence of substantial data on loss of once-common species (as is shown very clearly in much of Europe and is reported to be the case in North America and much of Asia) and also the pressing need to fund major analyses of birds and land use outside of Europe. This needs to be done at the strategic (global and regional) level and also as case studies of countries, regions, farming systems and species.

Key habitats affected by farming land use are forests, savanna, grassland, wetland, farmland and marine. Initial information suggests that for these habitats problems exist in:

- South America: main threats are deforestation, agricultural intensification and poor grazing management. In Argentina, Paraguay and Brazil, over half the globally threatened grassland species are threatened by agricultural change. Afforestation of grasslands and sugar, soya bean and coffee plantation management are considered problems in Bolivia and Brazil.

- Africa: main threats cited are agriculture and forestry. Agricultural change is cited as a threat to savanna throughout Africa and to grasslands in South Africa. Drainage of wetlands for farming is a continent-wide problem.

- Asia: China is important for wetlands, forests and grasslands threatened by agriculture and rapid economic growth, and farm development threatens farmland habitats. Changes in agriculture in the Indian subcontinent threaten grassland and wetland birds. Ancient patterns of settlement and land use are threatened across Asia.

As in Europe, the threats from farming do not diminish the importance of traditional approaches to species and site-based conservation, rather they strengthen the need for these to be properly resourced and for legal protection of species and sites to be made really effective. However, there is also a need to engage with governments who have not yet done enough to consider sustainable agriculture and policies to promote environmentally sensitive farming. This must be done through both strengthening national conservation organizations and authorities and by, when possible, applying international pressure on them. So what can bird conservationists do? I suggest the following strategy for beginning to resolve these problems. In doing so, I am caught in a conundrum between on the one hand the need to be realistic and moderate in the need for more resources and on the other hand a growing alarm at the pace of change in land use globally. 
First, we need to undertake more strategic and case study analyses of farming and birds to demonstrate clearly to ourselves and to our external advocacy targets the scale and nature of the problem. Second, we need to ensure that in regional and national conservation strategies (including the strategies for individual conservation organizations) that the need to provide resources for land use policy is clearly defined. Third, we need to deploy these resources to develop (through recruitment and training) expertise in land use policy and advocacy. Fourth, at national level, we need to build alliances with other environmental interests, consumer and rural development groups and, of course, farmers. Fifth, we need to develop effective ways of communicating internationally so as to exchange information (and resources), to learn from experience across the world and to bring pressure on key international agencies (such as the $\mathrm{EU}, \mathrm{UN}$ agencies, World Trade Organization and commercial organizations).

The above priorities will undoubtedly be difficult to achieve and will draw resources from a conservation movement stretched across all of its activities. I believe that by combining many existing resources, effective use of networking and technology and harnessing the enormous human resources of skill, enthusiasm and commitment in conservation that bird conservation can have an effective influence on agriculture throughout the World. If we fail, then the rapid pace of globalization of our economies, the technological and political developments in farming and many other pressures on land use will continue to exact a huge toll on our wildlife. We have little choice but to engage in the global debate on just how we should feed our planet in the twenty-first century.

\section{References}

BirdLife International (1996a) Nature conservation benefits of plans under the AgriEnvironment Regulation (EEC2078/92). Sandy, U.K.: Royal Society for the Protection of Birds.

BirdLife International (1996b) Preliminary analysis of land use change and globally threatened birds in the World. Cambridge, U.K.: BirdLife International.

BirdLife International (1997) A future for Europe's rural environment: reforming the Common Agricultural Policy. Sandy, U.K.: Royal Society for the Protection of Birds.

Cuff, J. A. and Rayment M. (1997) Working with nature in Europe. Sandy, U.K.: Royal Society for the Protection of Birds.

Pain, D. J. and Pienkowski, M. J. (1997) Farming and birds in Europe. London: Academic Press.

Rayment, M. (1995) The world grain trade. Sandy, U.K.: Royal Society for the Protection of Birds.

Tucker, G. M. and Heath, M. F. (1994) Birds in Europe: their conservation status. Cambridge, U.K.: BirdLife International.

Tucker, G. M. and Evans, M. (1997) Habitats for Birds in Europe. Cambridge, U.K.: BirdLife International.

\section{JIM DIXON}

Royal Society for the Protection of Birds, The Lodge, Sandy, Bedfordshire SG19 2DL, U.K. e-mail: jim.dixon@rspb.org.uk 